This item was submitted to Loughborough's Research Repository by the author.

Items in Figshare are protected by copyright, with all rights reserved, unless otherwise indicated.

\title{
Measurement and identification of asset-poor households: a cross-national comparison of Spain and the United Kingdom
}

PLEASE CITE THE PUBLISHED VERSION

https://doi.org/10.1007/s10888-010-9135-2

\section{PUBLISHER}

(C) Springer Nature

\section{VERSION}

AM (Accepted Manuscript)

\section{PUBLISHER STATEMENT}

This work is made available according to the conditions of the Creative Commons Attribution-NonCommercialNoDerivatives 4.0 International (CC BY-NC-ND 4.0) licence. Full details of this licence are available at: https://creativecommons.org/licenses/by-nc-nd/4.0/

\section{LICENCE}

CC BY-NC-ND 4.0

\section{REPOSITORY RECORD}

Azpitarte, Francisco. 2019. "Measurement and Identification of Asset-poor Households: A Cross-national Comparison of Spain and the United Kingdom". figshare. https://hdl.handle.net/2134/36508. 


\title{
Measurement and Identification of Asset-Poor Households: A Cross-National Comparison of Spain and the United Kingdom*
}

\author{
Francisco Azpitarte** \\ STICERD, London School of Economics
}

\begin{abstract}
This paper is concerned with the analysis of the wealth dimension of poverty in developed countries, which can hardly be measured by means of the information on household income. We focus in identifying the group of households that lack enough wealth holdings to sustain them during a period of economic crisis in order to quantify asset poverty, and its demographic weight, in two industrialized countries with particularly different household demographics and saving attitudes such as Spain and the United Kingdom. Our results show that the age profile of the asset poor is remarkably similar in the two countries. In both it is individuals in households whose head is under 45 years old who are more likely to be asset poor. However, some country-specific differences also arise. For instance, the incidence of wealth poverty in the United Kingdom is about twice that of Spain. Using counterfactual analysis we find that, although the different household demographics clearly contribute importantly to this result, there remains a significant part of the asset-poverty gap which is not explained by this relevant factor.
\end{abstract}

\footnotetext{
* I wish to acknowledge the financial support from the Xunta de Galicia (Programa de Estruturación de Unidades de Investigación en Humanidades e Ciencias Sociais 2006/33 and FEDER founds) and the Spanish Ministerio de Ciencia e Innovación (SEJ2007-67911-C03-01/ECON). This paper is based on work carried out during my visit to the Institute for Social and Economic Research, University of Essex supported by the EU Improving Human Potential Programme.

** Correspondence to: Francisco Azpitarte, STICERD-London School of Economics and Political Science, Houghton Street, London WC2A-2AE (F.Azpitarte@lse.ac.uk).
} 


\section{Introduction}

Important contributions to welfare economics have recognized the multidimensional character of poverty. In regular poverty analysis, however, families' well being has been traditionally identified with the value of total household income. In fact, official poverty measures in both the U.S. and the E.U. countries are based on household income data. In any case, as Bourguignon and Chakravarty (2003) concluded, "Income as a sole indicator of family well-being is inappropriate and should be supplemented by other attributes and variables ...". In particular, wealth is an excellent candidate to be considered, given its important contribution to families' intertemporal welfare. Thus, beyond the direct income flows provided by assets, wealth is one of the main components of a household's-safety net and an important determinant of the vulnerability of the household to income shocks. Therefore, assets are central to the economic security of families, as they are the main source of liquidity in times of economic hardship, such as those derived from unemployment, sickness, or family break-up. Furthermore, in a context of imperfect capital markets, the lack of assets may prevent households from taking risky actions that could imply a future increase in household income, such as running a new business or quitting a job in order to look for a more desirable one, which obviously implies an important cost in terms of household lifetime welfare.

In this paper we focus on the analysis of wealth poverty. We claim that the analysis of this dimension of welfare complements the traditional income approach to poverty as it allows us to identify other forms of deprivation that cannot be measured using regular income, clearly contributing to improve our knowledge about poverty and its different dimensions. In particular, we will identify as asset-poor those households that lack enough wealth holdings to sustain them during a period of economic hardship. We argue that the identification of these households is an important issue for welfare policy design, as it allows us to determine which households are more vulnerable to income shocks and, consequently, more likely to experience economic deprivation in times of economic crisis like the current one. In addition, the limited capacity of these households for taking risky actions may lead them to a situation of chronic vulnerability to poverty after a bad income shock, as they may progressively move towards a poor welfare steady state characterized by low levels of both income and wealth (Barret and McPeak, 2006).

Our first goal is to measure and characterize asset-poor households in two industrialized countries with particularly different household demographics and saving attitudes such as Spain and the United Kingdom. To the best of our knowledge, our work is the first attempt to analyze the extent of asset-poverty in Spain, provided that, until 2002, there was an absolute lack of adequate data for undertaking this type of research. Thus, our analysis complements previous research papers on poverty in Spain that use household income as welfare indicator (Cantó et al. 2007, 2006, Bárcena and Cowell 2006, Ayala and Palacio, 2000), by focusing on the wealth dimension of welfare. In particular, the information on families' wealth holdings contributes to improve our knowledge about people's living conditions, and consequently, it allows us to identify and describe more accurately the situation of those households that are in greater need.

Results for a Southern European country like Spain will be compared with those obtained for an Anglo-Saxon country such as the United Kingdom. This comparison turns out to be most interesting for various reasons. As Bover et al. (2005) show, the portfolio composition differs significantly between these countries, with Spanish households showing a larger preference for housing wealth, while financial assets are relatively more important in the United Kingdom. Most importantly, the comparison is interesting due to the differences in the demographic structure and the household formation process observed in these two countries (Duclos and Mercader-Prats, 
1999). In Spain, as in other Mediterranean countries, the share of young people living with their parents and the proportion of elderly co-residing with an adult are traditionally much larger than in Northern European countries like the United Kingdom (Reher, 1998). Consequently, given that the household structure of the two countries differs significantly, regarding the age distribution and the type of living arrangements, we expect to find important differences in the saving behaviour and thus, in the level of accumulated wealth over the life cycle (Gourinchas and Parker, 2002), which are likely to condition the number and composition of asset-poor households.

In order to assess these differences, we provide evidence on the link between household structure and the incidence of asset-poverty. In particular, following Bover (2008) we apply counterfactual analysis to measure the contribution of the demographic structure to differences in wealth-poverty rates. Our results suggest that, in the particular cases of the United Kingdom and Spain, this contribution is significant. Note, however, that there remains a large part of the difference that is not explained by the demographic structure. Indeed, other factors may have a large role on the household level of accumulated wealth. In particular, a relevant one will be linked to the differences in the degree of generosity of the Social Protection System which will imply differences in incentives for households in order to save for unprotected risks. ${ }^{1}$ Thus, for instance, as a recent comparison of social security systems across OECD countries by Alonso (2009) suggests, the gross replacement rate of social security benefits, measured as the ratio of those benefits to average net earnings, is more than 2.5 times larger in Spain than in the United Kingdom. Furthermore, these two countries also differ regarding the extent of coverage of their unemployment insurance systems. Thus, while in Spain the average replacement rate is above 67 percent and the benefit duration is 21 months, in the United Kingdom these figures are about 54 percent and 6 months (OECD, 2006). We believe these differences in public insurance programs certainly influence the wealth accumulation process in Spain and the United Kingdom. However, the contribution of this factor to the asset-poverty gap between these two countries is left for further research.

The paper is organized as follows. In Section 2, we present a revision of the research on welfare and poverty that has considered the contribution of wealth holdings. Section 3 describes the data sources we use in the analysis and shows the portfolio composition of Spanish and British households. In Section 4, we report the incidence of asset-poverty and the identification of asset-poor households in Spain and the United Kingdom, and we summarize the main differences between the household structures of these two countries. We complete this section presenting a decomposition of the wealth-poverty gap using counterfactual analysis. Finally, in Section 5 we detail our main conclusions.

\section{Assets and Welfare}

The question of how to integrate wealth into welfare and poverty analysis has received an increasing attention in recent years. In the traditional income approach, the contribution of wealth to families' well-being is partially measured, as it only considers the direct income flow provided by assets. However, wealth is also important for the security of families, since assets constitute the main source of liquidity in times of economic hardship. Thus, two alternative approaches have

\footnotetext{
1 Hubbard et al. (1995) show theoretically that asset means-tested social insurance programs discourage households' savings, especially that of those with expected low permanent income. For an excellent survey on the saving behaviour literature, see Browning and Lusardi (1996).
} 
been proposed in the literature to quantify the contribution of assets to households' welfare. In the first approach, the main idea is to integrate both income and wealth into a single measure of welfare. An important issue that arises when trying to combine these two variables is that while income is a flow variable, wealth is a stock variable. The income-net worth measure proposed by Weisbrod and Hansen (1968) solves this problem using the annuity method to convert net worth into a flow of resources, such that, the economic welfare of a unit is equal to its current income plus the lifetime annuity value of its current net worth. ${ }^{2}$ An important consequence of the incomenet worth measure is the change it promotes in the relative and absolute welfare of various segments of the population, especially on the aged, who, when using this measure, appear to be considerably better off than a current income measure would show. Regarding poverty, various authors have analyzed the impact of this measure on the incidence of poverty (Zagorsky 2006, Short and Ruggles 2006, Van den Bosch 1998, Wolff 1990). All these papers proceed by establishing an income poverty line, and identifying a household as poor whenever its annuity from wealth is not enough to compensate the income poverty gap. The results suggest an important decline in the poverty rate when the annuity from wealth is considered, with the largest reduction being observed for the elderly. Ruggles and Williams (1989) analyzed the effect of considering asset holdings on poverty entries and the duration of poverty spells when financial assets can be used to fill income poverty gaps. They found that more than one-third of the poverty spells were eliminated and that the remaining poverty spells were on average longer after assets were accounted for than when they were not.

Alternatively, the second approach looks only at the wealth dimension of welfare independently of its relationship with income, and the idea is to measure the extent to which households have enough asset holdings to overcome a period of economic hardship. This is the approach adopted by Hubbard et al. (1995) and Caner and Wolff (2004) to analyze wealth-poverty in the U.S., and it is precisely the one we follow in this paper. We argue that, given that wealth poverty and the contribution of wealth to families' welfare are unexplored issues in the case of Spain, this approach is more suitable for a first approximation to the study of asset-poverty in Spain than the previous one, as it allows us to focus exclusively on the wealth dimension of welfare. Hubbard et al. (1995) studied how the existence of asset-based, means-tested social welfare programs influence the number of low-wealth households, where this group includes every household with net-worth less than annual current income. According to Caner and Wolff (2004), a household is considered wealth-poor whenever its wealth resources are not sufficient to meet the basic needs of the members for a limited period of time; here, basic needs are measured using family-size conditioned poverty thresholds, and the period of time is set equal to three months. Using this definition of poverty, these authors studied the evolution of wealth-poverty in the U.S. over the period 1984-1999. They found that, despite the fact that during that period the poverty rate remained constant, the severity of poverty increased. Their results show that about 26 percent of U.S. households were net-worth poor in 1999 and this percentage increases up to 40 percent when the housing component is excluded. Lastly, their results show that the probability of being asset-poor increased for young households whose heads hold a low level of education or do not work.

\footnotetext{
2 The value of the lifetime annuity is equal to $\mathrm{NW}^{*}\left(r /\left(1-(1+r)^{-n}\right)\right)$, where $N W$ is the value of net worth, $r$ is the interest rate, and $n$ measures the life expectancy.
} 


\section{Wealth Data Sources and the Portfolio Composition in Spain and the United Kingdom}

\subsection{Wealth Data Sources}

To study the incidence of wealth-poverty in Spain, we draw on data from the first wave of the Spanish Survey of Household Finances (Encuesta Financiera de las Familias, EFF) conducted by the Bank of Spain in 2002. ${ }^{3}$ The EFF is a survey on wealth aimed at providing detailed data about the wealth holdings of Spanish households. Thus, the first wave contains information about the ownership status and the value of a wide range of real and financial assets, as well as information on the debt holdings of household's members. For the United Kingdom, we use data from the tenth wave of the British Household Panel Survey (BHPS). ${ }^{4}$ The BHPS is an annual survey that provides multiple socioeconomic information about British households since 1991. In particular, every wave of the BHPS contains data on the value of the principal residence, other real estate, the net value of vehicles, and the household's mortgage debt. Moreover, in the tenth wave, this information is complemented with a specific module where household members are asked to report the value of financial assets and non-mortgage debt, which makes this wave of the BHPS the most suitable available dataset to describe British households' wealth. ${ }^{5}$

The first wave of the Spanish survey includes a sample of 5,143 households. The EFF provides complete information on households' wealth holdings given that if a household fails to respond to the complete questionnaire, an imputation method ${ }^{6}$ is used to compute five imputed values for each missing value. ${ }^{7}$ In the case of the tenth wave of the BHPS, only 5,321 households out of the 8,761 initially interviewed reported all the required information about wealth holdings. In order to control for the potential bias this selection may cause, we weight each complete observation with the inverse of the probability that a household completes the full questionnaire. ${ }^{8}$ An important difference between the Spanish and British samples is the oversampling of wealthy households, as this group of households is over-represented only in Spain. However, this will not affect our results, since the representativeness of this sample is guaranteed by the use of appropriate sample weights provided in the survey.

The information in the EFF allows us to construct a net worth measure for Spanish households defined as the sum of the value of real and financial assets minus the current value of debts. ${ }^{9}$ Importantly, the BHPS does not provide information on some of the assets and debts included in the EFF. Thus, in order to allow for full comparability, we define a common net worth measure

\footnotetext{
${ }^{3}$ For a detailed description of the methodology used in the first wave of the EFF, see Bover (2004).

${ }^{4}$ For a detailed description on the methods used in the BHPS, see Taylor et al. (2007).

5 Indeed, this dataset has been included in the Luxembourg Wealth Study (LWS) to provide information about British households' wealth. The LWS is an international project launched in 2003, whose primary goal is to harmonize existing micro-data on wealth. For a discussion about wealth surveys comparability and some preliminary results using the LWS database, see Sierminska et al. (2006).

${ }^{6}$ The imputation method is the Federal Reserve Imputation Technique Zeta (Fritz). This is a stochastic method with a sequential and iterative structure. For more details, see Kennickell (1998 and 2000).

${ }^{7}$ Following the recommendations in the EFF, we make inferences combining the information in the five imputed datasets. In particular, the estimates presented here correspond with the average of the five complete data estimates.

${ }^{8}$ We estimate this probability by means of a regression on household characteristics. The details of the estimation are described in the appendix.

${ }^{9}$ For a complete description of the net worth measure and the other definitions of wealth used in the analysis see the appendix.
} 
that only includes those items reported in both surveys. ${ }^{10}$ Further, in some parts of the analysis, we will decompose this net worth measure in its two main components: housing and non-housing wealth. The former is the sum of the net values of all the real estate owned by the household, while non-housing wealth includes the rest of real and financial assets and the value of nonmortgage debt.

In the BHPS, every individual who has financial assets or non-mortgage debt is asked to report if it is held on her sole name or if it is jointly held with someone else. ${ }^{11}$ The possibility that an asset or debt may not be held solely by one individual generates problems when implementing a measure of household wealth, given that some assets may be double-counted. Following Banks et al. (2003), we address this issue with a bounding approach. In particular, we construct an upper and a lower bound for those assets and debts in which joint ownership is reported. ${ }^{12}$ Then, we use these values to compute an upper and lower bound of household net worth. Thus, to compute the upper value, we add the upper bound of financial assets and subtract the lower bound of the non-mortgage debt, whereas the lower bound is computed using the lower bound of assets and the upper bound of the debt component. Fortunately, the results we get are not sensitive to the alternative employed. ${ }^{13}$

Both the EFF and the BHPS also contain data on the different sources of income. In particular, as we describe in the next section, in order to construct the wealth poverty thresholds, we will use both annual and monthly household gross income (before taxes and contributions to the Social Security System). This variable is the sum of capital income, wages and salaries, selfemployment earnings, unemployment benefits, private and public retirement pensions, and other transfers received by any household member. Finally, the unit of analysis we use in this paper is the household. In both surveys, a household is defined as including all individuals living together in the same dwelling, even if, as in the case of Spain, sharing expenses is an additional requirement to form a household. Moreover, since we are interested in the ability of families to overcome times of economic crisis using accumulated wealth holdings, we take into account differences in needs across households. For doing so, we compute the equivalent values of both income and wealth variables using the modified OECD equivalence scale, which weights the first adult by 1 , the second and all subsequent adults by 0.5 , and every household member below 14 years of age by 0.3 .

\subsection{The Portfolio Composition}

We start our analysis by looking at the asset portfolio composition of Spanish and British households. In particular, in Table 1, we show, for each wealth component both the percentage of households owning the particular asset and its share in total assets. For the case of Spain, two

\footnotetext{
10 The cost of comparability can be measured by the weight that the excluded assets have of the Spanish portfolio (about 15 percent of total assets).

11 In contrast with the BHPS, where information on these assets is collected at individual level, in the EFF this information is collected at household level, so in the case of Spanish households there is no need to aggregate the information on ownership and asset values provided by household members.

12 The upper bound is computed assuming that any jointly held asset is held solely by the individual, while the lower bound is calculated assuming that the individual only owns a fraction $1 / \mathrm{N}$ of the asset, where $\mathrm{N}$ is the number of adults in the household.

13 Indeed, the results we present henceforth are computed using the upper bound of wealth holdings. The results with the lower bound are available from the author upon request.
} 
versions of the portfolio are presented: first, we consider every asset for which information in the EFF is provided; second, in order to make a sound comparison of the Spanish and the British portfolios, we include only those assets for which information is reported in both the EFF and the BHPS.

Table 1

The portfolio composition in Spain and the United Kingdom (all variables in percentage, $n$.a. $=$ not available)

\begin{tabular}{|c|c|c|c|c|c|}
\hline & \multicolumn{3}{|c|}{ Spain } & \multicolumn{2}{|c|}{ United Kingdom } \\
\hline & $\begin{array}{c}\% \text { of } \\
\text { owners }\end{array}$ & $\begin{array}{c}\% \text { of total } \\
\text { assets }\end{array}$ & $\begin{array}{c}\% \text { of total } \\
\text { assets (1) }\end{array}$ & $\begin{array}{c}\% \text { of } \\
\text { owners }\end{array}$ & $\begin{array}{c}\% \text { of total } \\
\text { assets }\end{array}$ \\
\hline Real Assets & & 88.3 & 91.0 & & 82.3 \\
\hline Principal residence & 81.9 & 52.2 & 64.4 & 69.1 & 71.3 \\
\hline Other real estate & 30.1 & 18.6 & 23.0 & 7.5 & 8.2 \\
\hline Vehicles & 73.7 & 3.3 & 3.6 & 69.6 & 2.9 \\
\hline Business equities & 11.5 & 6.6 & & n.a. & \\
\hline Other consumer durables & 100.0 & 7.6 & & n.a. & \\
\hline Financial Assets & & 11.7 & 9.0 & & 17.7 \\
\hline Saving and deposits & 16.8 & 2.1 & 2.6 & 73.6 & 8.3 \\
\hline Shares & 12.5 & 3.2 & 4.0 & 25.0 & $9.4(2)$ \\
\hline Mutual and investment funds & 7.2 & 1.1 & 1.4 & 17.8 & \\
\hline Fixed income securities & 1.9 & 0.2 & 0.3 & 28.5 & \\
\hline Other financial assets & 4.5 & 0.6 & 0.7 & 5.1 & \\
\hline Current accounts & 97.7 & 2.5 & & n.a. & \\
\hline Private pension schemes & 23.1 & 1.7 & & n.a. & \\
\hline Life insurance programs & 1.1 & 0.2 & & n.a. & \\
\hline Total & 100 & 100 & 100 & 100 & 100 \\
\hline Debts & & 7.6 & 9.4 & & 19.2 \\
\hline Mortgage debt & 28.1 & 6.3 & 7.8 & 40.5 & 17.5 \\
\hline Non-mortgage debt & 24.9 & 1.2 & 1.5 & 43.5 & 1.7 \\
\hline
\end{tabular}

Source: Author's calculations using EFF 2002 and BHPS 2000

(1) Total assets adjusted for comparison with the United Kingdom. For a description of the real and financial assets included in both the EFF and the BHPS see the appendix.

(2) It is the share accounted by investments including shares, mutual and investment funds, fixed income securities, and other financial assets.

The portfolio composition is the product of two decisions-a discrete choice of which assets to hold and a second choice of how much to hold of each particular asset (Hubbard, 1985). These decisions are affected by several factors, such as taxes, relative prices of assets, as well as other institutional and cultural elements, like the provision of social security or preferences about risk. All these factors may vary across countries, and clearly, this will cause important variation in the asset portfolios of their households. Indeed, our results highlight important differences in the portfolio composition of Spain and the United Kingdom. Thus, as it has been already documented in the literature, Spain exhibits a large preference for less-liquid assets, especially for housing wealth (Bover, 2004), while the British households show a significantly higher share of financial wealth. Almost 82 percent of Spanish households own their main residence, and more than 30 percent own some other real estate. Indeed, Spain presents the largest proportion of homeowners among OECD countries, where this proportion ranges from the 40 percent observed 
for Germany to the 80 percent observed for Spain, Greece, and Italy (Christensen et al. 2005). The proportion of households that own their main residence in the United Kingdom is around 70 percent, which is lower than the figure obtained for Spain. The biggest difference is in the proportion of households in possession of other real estate properties, which is more than double in Spain, compared to the United Kingdom. Thus, real assets have a significantly larger importance in Spain than in the United Kingdom. Indeed, their share in the Spanish portfolio is above 90 percent, whereas in the British one they represent around 82 percent of total assets. Clearly, the other side of the coin is that British households reveal a larger preference for more liquid assets in comparison with Spanish households. Indeed, for every financial asset for which information is reported in both surveys, the rate of ownership in the United Kingdom is larger than in Spain. For instance, only 12 percent of the Spanish households hold some type of share, while in the United Kingdom, this proportion is about 25 percent. If compared with other countries included in the Luxembourg Wealth Study (LWS), ${ }^{14}$ the figure for Spain is similar to that of Italy, where the number of shareholders is around 11 percent of the population. Meanwhile, the rate of ownership in the United Kingdom is more similar to that observed for the United States, Norway, and Sweden, where the number of owners is about 30 percent of the population. The low presence of financial assets in the Spanish households' portfolio explains the lower weight of financial assets have within total wealth compared with the Britain (about 9 versus 17 percent). Finally, regarding mortgage and non-mortgage debt, the number of households in debt in the United Kingdom is significantly larger than in Spain, given that the debt component represents about 19 percent of the British households total assets, while in Spain, its share is below 10 percent. Importantly, current debts highly influence households' vulnerability as they may condition the capacity of households to overcome periods of economic stress. Thus, in the presence of incomplete markets, the amount of liquid wealth required to cope with income shocks increases with the value of outstanding debt. Consequently, the greater number debt holders observed in the United Kingdom would imply, all other things being equal, that British households are more vulnerable to economic shocks than their Spanish counterparts.

\section{Asset-Poverty in Spain and the United Kingdom}

\subsection{Definitions and Poverty Rates}

We want to identify vulnerable households that cannot rely on their wealth holdings to sustain their welfare level during a period of economic hardship. The wealth variables we use are the equivalent household net worth and its two main components, namely, housing and non-housing wealth. Regarding the definition of a period of hardship, we follow Caner and Wolff (2004) and will consider as asset-poor those households that are not able to maintain themselves at a significant level of welfare by running down their wealth over three months. ${ }^{15}$

\footnotetext{
${ }^{14}$ Austria, Canada, Cyprus, Finland, Germany, Italy, Norway, Sweden, United States, and the United Kingdom are currently contributing to the LWS data base with their national datasets. For some preliminary results using this database, see Sierminska et al. (2006).

15 These authors argue that the expected duration of an unemployment spell in the United States is around three months. In Spain and the United Kingdom the average unemployment period is about eight and ten months, respectively (Tatsiramos, 2006). Despite this difference, we use the three-month period to guarantee comparability with previous results in the literature. Moreover, results from the robustness analysis available upon request, show that the results obtained with the three months period still hold when country specific average unemployment spells are considered.
} 
More precisely, we will use three definitions of asset-poverty. First, we consider as asset-poor every household with net worth less than or equal to zero. We use this definition for comparative reasons, since the proportion of households with non-positive wealth is reported in most of the empirical wealth distribution analysis, which allows us to compare Spain and the United Kingdom with other countries. Moreover, these households are most likely to be unable to maintain a minimum level of welfare spending down their assets because of the serious difficulties they face in order to transform their wealth into consumption in times of economic crisis. Second, following Caner and Wolff (2004), we consider as asset-poor those households for which their equivalent net worth is not sufficient for sustaining household members above the monthly income poverty line for more than three months. ${ }^{16}$ This definition slightly differs from that used by these authors, given that we use a relative income poverty line instead of an absolute one. ${ }^{17}$ We argue that our choice is consistent with the relative criterion adopted in the official estimation method of income poverty in the European Union. ${ }^{18}$ Thus, given our interest in the capacity of Spanish and British households to overcome periods of income poverty, we claim that a relative approach is more suitable than an absolute one in this case. Finally, our third definition of wealth-poverty is related to that used by Hubbard et al. (1995). According to their definition, a household should be identified as asset-poor if its equivalent net worth is smaller than its quarterly household equivalent income. ${ }^{19}$ Interestingly, these definitions only differ on the minimum welfare level required to be maintained by means of wealth holdings, which further allows us to check the sensitivity of our results to the way poverty is measured. In the first case, the level is equal to zero. In the second case, it is equal to three times the monthly income poverty line, and in the last case the poverty line is set at the current quarterly household income level. Notice, however, that the third definition of the poverty threshold implies a wealth-poverty approach quite different to that suggested by the other two definitions. Thus, in contrast with the first two poverty lines which are common to all households, the third one represents a household-specific minimum level of welfare that increases with the level of household income. ${ }^{20}$ Indeed, with this income-specific poverty line, it is possible that households with low wealth holdings may not be considered as asset-poor if they also have low income, while households with a large amount of wealth may be identified as wealth-poor simply because their wealth is relatively low compared with their income.

Table 2 reports asset-poverty rates for Spain and the United Kingdom. In Spain, the proportion of households identified as asset-poor ranges between 2 and 11 percent, depending on the definition of poverty considered. However, whatever the definition used, if we look at wealthpoverty by wealth components, the incidence is in most of the cases larger for non-housing than for housing wealth. Indeed, about 15 percent of Spanish households are identified as poor in terms of housing wealth, regardless of the criteria employed, whereas in the case of non-housing wealth, the proportion of poor households ranges between 8 and 51 percent, depending on the definition used. The comparison between Spain and the United Kingdom highlights important

\footnotetext{
16 The poverty line in each country is set equal to 60 percent of the median monthly household equivalent income.

17 In particular, Canner and Wolff (2004) identify as asset-poor those households that lack enough wealth resources to meet their basic needs over three months, where basic needs are measured using the family-size conditioned minimum consumption thresholds computed using the Consumer Expenditure Survey.

18 We refer to the so-called Laeken poverty indicators, which are aimed to monitor the progress in fighting against poverty and social exclusion in European Union countries.

19 Quarterly income is derived from annual income divided by four. Hubbard et al. (1995) define "low-wealth" households as those whose net worth is below their total annual income.

20 Indeed, results not presented here that are available upon request, show that in both Spain and the United Kingdom, the third poverty line is below the second for households in the bottom quintile of the income distribution, while the opposite occurs for households in the upper quintiles.
} 
Table 2

Asset-Poverty in Spain and the United Kingdom

(percentage of households)

\begin{tabular}{llll}
\hline \hline & & \multicolumn{2}{c}{ Spain vs. United Kingdom (1) } \\
\cline { 3 - 4 } & Spain & Spain & United Kingdom \\
\hline Net worth & & & \\
\% with zero or negative wealth & 2.0 & 12.2 & 19.7 \\
$\%$ with wealth $\leq 3 \times$ monthly income poverty line & 10.3 & 13.1 & 27.5 \\
$\%$ with wealth $\leq$ quarter income & 11.1 & 13.5 & 29.5 \\
Housing wealth & & & \\
$\%$ with zero or negative wealth & 15.4 & 15.4 & 29.9 \\
$\%$ with wealth $\leq 3 \times$ monthly income poverty line & 15.7 & 15.7 & 30.5 \\
\% with wealth $\leq$ quarter income & 15.9 & 15.9 & 31.7 \\
Non-housing wealth & & & \\
\% with zero or negative wealth & 8.5 & 70.1 & 38.7 \\
\% with wealth $\leq 3 \times$ monthly income poverty line & 44.2 & 75.7 & 55.9 \\
\% with wealth $\leq$ quarter income & 51.2 & 80.8 & 63.0 \\
\hline
\end{tabular}

Source: Author's calculations using EFF 2002 and BHPS 2000

(1) To compare Spain with the United Kingdom, the common net worth measure including only the value of those assets for which information is reported in both the EFF and the BHPS was used. A detailed description of the wealth variables is provided in the appendix.

differences between these two countries. Indeed, the asset-poverty rate among British households is significantly larger than that of Spain, independent of the definition of poverty used. ${ }^{21}$ For instance, the share of households with zero or negative net worth in the United Kingdom is above 19 percent, whereas in Spain, this percentage is about 12 percent. ${ }^{22}$ If we compare our results with those for other countries included in the LWS, we find that the results obtained for the United Kingdom are similar to those obtained for countries like the U.S. and Canada, where the proportion of non-positive wealth holders is around 23 percent. ${ }^{23}$ Results for Spain, instead, are closer to those found for Italy and Finland, where the share of households

\footnotetext{
${ }^{21}$ The fact that the common net worth measure does not include the value of some assets like pension plans, life insurance or business equities could contribute to explain the asset-poverty gap between these two countries. Indeed, given the different development of financial markets in Spain and the United Kingdom, one could speculate that this type of assets is more commonly held by British households which would bias the estimate of the wealth-poverty gap. However, there are factors that could limit the influence of these assets. Thus, empirical evidence available for Spain and other countries in the LWS suggests that the portfolio share and the rate of ownership of these assets at the bottom of the distribution is rather low, especially in the case of business equities whose value is highly concentrated in the hands of the rich (Azpitarte 2008, Bover et al. 2005).

22 We checked the robustness of this result using a wealth-poverty threshold $W=s Y$, where $Y$ is the annual equivalent household income and $s$ takes values $\{0,0.05,0.1,0.15, \ldots, 1\}$. In most of the cases, the incidence of assetpoverty in the United Kingdom is more than twice that observed for Spain.

${ }^{23}$ Sierminska et al. (2006) report some preliminary results using the LWS database for Canada, United States, Italy, Sweden, and Finland. In contrast with our common net worth variable, their net worth variable includes the value of transaction accounts, life insurance, and consumer durables other than vehicles.
} 
with zero or negative wealth holdings ranges from 10 to 17 percent. Clearly, these results suggest that most of the wealth-poverty differentials between Spain and the United Kingdom are driven by the housing wealth component. Indeed, the share of British households that do not accumulate housing wealth is twice that of Spain (30 versus 15 percent). Conversely, the incidence of poverty in terms of non-housing wealth is larger among Spanish households, ranging between 70 and 80 percent, while in the United Kingdom the poverty rate considering these assets is between 38 and 63 percent. This result is consistent with the larger rate of ownership observed for this type of assets in the United Kingdom in comparison with Spain.

\subsection{The Identification of Asset-Poor Households}

As stated in the introductory section, the main aim of this paper is to identify the characteristics of asset-poor households in Spain and the United Kingdom. For this purpose, Table 3 presents the incidence and distribution of wealth-poor households by socioeconomic characteristics in the two countries. In particular, the results in this table correspond to the case in which the wealth-poverty threshold is set equal to three times the monthly income poverty line. ${ }^{24}$ Interestingly, the figures suggest that the incidence of wealth-poverty is larger among households at early stages of the life cycle. ${ }^{25}$ Thus, households below 45 years of age, especially those under 25 , are overrepresented among the asset-poor in both countries. The credit constraints typically faced by the youth (Jappelli, 1990) and the fact that most of these households have not yet started their wealth accumulation process, are determinants in explaining this result. However, we also find a group of households at middle or final stages of their life cycle that have not accumulated assets. Thus, despite the lower incidence of asset-poverty observed for households above 45 years of age compared with other households, this group accounts for almost 50 percent of the asset-poor population. Importantly, the cross-country comparison reveals that, independent of the group considered, the incidence of wealth-poverty in the United Kingdom is larger than in Spain. By age groups, the largest difference is observed for the elderly. Indeed, for this group, the incidence of asset-poverty in the United Kingdom is more than 2.5 times that in Spain, while for the youngest households, this number is around 1.5 times. Lone-parent households and households whose head is inactive or low educated are particularly exposed to wealth-poverty in the two countries, even though these households are markedly more vulnerable in the United Kingdom, as reflected by the fact that the asset-poverty rates for these groups in the United Kingdom are about three times those observed in Spain. Despite the larger incidence observed for the United Kingdom, the composition of the asset-poor population is very similar in both countries, with only some slight differences regarding the youngest, the eldest, and one-member households, whose presence among the asset-poor is larger in the United Kingdom. Interestingly, the incidence and the presence of female-headed households in the wealth-poor population is larger in the United Kingdom than in Spain, which may be related to differences in the women's integration in the

\footnotetext{
24 In contrast with the zero-negative poverty threshold, this criterion allows us to identify a set of asset-poor households within a minimum acceptable number of households. Moreover, unlike the quarterly income poverty line, the identification of asset-poor households with this threshold does not depend on the relationship between income and wealth within the household. In any case, the asset-poverty rankings do not change when these two alternative thresholds are employed.

${ }^{25}$ We identify the age of the household using the information on the age of the household head. In both the BHPS and the EFF, the reference person is defined as the person responsible for the accommodation and household finances.
} 
national labour markets in these countries and its consequences on the formation of this type of household. Thus, although the female labour participation rate has steadily increased in Spain since the opening of the economy in the 60's, there still exists a substantial difference in participation rates between Spain and the United Kingdom, especially in the case of married mothers (Mumford and Parera 2001, Costa 2000).

In addition to the description of the asset-poverty profile, it is also interesting to identify more precisely the socioeconomic characteristics that have a larger impact on the probability of being asset-poor. To do so, we estimate a logit model in which the dependent variable is a wealthpoverty indicator variable that assigns a value 1 if the household is identified as asset-poor, and zero otherwise. This model is thought to serve simply as a statistical description of the association between the wealth status and households' characteristics. In particular, we consider various characteristics of the household, such as the sex, age, educational level, and labour status of the head, as well as other variables regarding living arrangements, as explanatory variables that can condition the ability of households to accumulate assets. Lastly, sample weights are used in order to run the regressions. As Table 4 shows, the results are rather similar for both countries. For instance, in Spain, young households, especially those under 25 years old, are the most vulnerable to wealth-poverty. Moreover, the probability of asset-poverty decreases for households whose head is over 55 years of age, and especially for those whose head is above 75. Interestingly, living arrangements are an important factor that affects poverty risk in both countries. Thus, single and lone-parent households have a greater possibility of being poor, especially in the United Kingdom, as reflected by the magnitude and significance of these estimates for this country. Importantly, in both the United Kingdom and Spain, households with a low expected lifetime income face a higher risk of wealth-poverty. Thus, households whose head is low-educated or inactive non-retired are more likely to be asset-poor. 
Table 3

Socio-economic characteristics of asset-poor households in Spain and the United Kingdom (all variables in percentage)

\begin{tabular}{|c|c|c|c|c|c|c|}
\hline & \multicolumn{3}{|c|}{ Spain } & \multicolumn{3}{|c|}{ United Kingdom } \\
\hline & \multirow{2}{*}{ Population } & \multicolumn{2}{|c|}{ Asset-poor } & \multirow{2}{*}{ Population } & \multicolumn{2}{|c|}{ Asset-poor } \\
\hline & & Incidence & Share & & Incidence & Share \\
\hline All & 100 & 13.1 & 100 & 100 & 27.5 & 100 \\
\hline \multicolumn{7}{|l|}{ Age and sex of the $h h$. head } \\
\hline$<25$ & 1.4 & 48.2 & 5.2 & 5.0 & 74.6 & 10.8 \\
\hline $25-34$ & 12.9 & 22.5 & 22.1 & 15.0 & 44.4 & 21.2 \\
\hline $35-44$ & 22.0 & 14.9 & 25.0 & 18.6 & 26.2 & 18.1 \\
\hline $45-54$ & 19.8 & 11.8 & 17.7 & 16.1 & 16.9 & 10.9 \\
\hline $55-64$ & 16.4 & 8.1 & 10.2 & 13.3 & 19.9 & 10.9 \\
\hline $65-75$ & 17.4 & 8.9 & 11.9 & 14.9 & 20.5 & 11.2 \\
\hline$>74$ & 10.2 & 10.2 & 7.9 & 17.1 & 28.7 & 16.9 \\
\hline Male & 66.1 & 12.1 & 61.4 & 55.5 & 21.1 & 44.0 \\
\hline Female & 33.9 & 14.9 & 38.6 & 44.5 & 36.1 & 56.0 \\
\hline \multicolumn{7}{|l|}{ Household size } \\
\hline 1 person & 15.2 & 22.9 & 26.7 & 36.4 & 38.3 & 44.0 \\
\hline 2 people & 25.7 & 11.4 & 22.3 & 32.0 & 18.7 & 23.6 \\
\hline 3 people & 24.3 & 11.3 & 20.9 & 14.2 & 27.2 & 14.6 \\
\hline 4 people & 24.3 & 10.0 & 18.5 & 11.7 & 22.4 & 10.4 \\
\hline 5 or more people & 10.6 & 14.3 & 11.6 & 5.7 & 33.3 & 7.4 \\
\hline \multicolumn{7}{|l|}{ Household type } \\
\hline One adult, without children (3) & 15.2 & 22.9 & 26.7 & 36.4 & 38.3 & 44.1 \\
\hline One adult, with children & 0.8 & 22.8 & 1.4 & 4.4 & 64.5 & 7.7 \\
\hline More than one adult, without & 57.0 & 9.8 & 42.8 & 39.9 & 16.8 & 27.3 \\
\hline More than one adult, with children & 27.0 & 14.1 & 29.1 & 19.4 & 28.2 & 20.9 \\
\hline \multicolumn{7}{|l|}{ Civil status of the hh. head } \\
\hline Never married & 11.1 & 22.7 & 19.2 & 16.2 & 48.6 & 24.4 \\
\hline Married & 71.2 & 10.6 & 57.8 & 52.6 & 17.6 & 36.9 \\
\hline Divorced & 5.1 & 26.0 & 10.2 & 14.2 & 43.3 & 20.7 \\
\hline Widow & 12.6 & 13.2 & 12.8 & 17.0 & 32.3 & 18.0 \\
\hline \multicolumn{7}{|l|}{ Education of the $h h$ head.(4) } \\
\hline Low & 59.2 & 13.70 & 61.9 & 55.1 & 34.8 & 66.1 \\
\hline Medium & 25.7 & 13.7 & 27.0 & 33.7 & 21.8 & 27.4 \\
\hline High & 15.1 & 9.6 & 11.1 & 11.2 & 15.9 & 6.5 \\
\hline \multicolumn{7}{|l|}{ Labour status of the hh. head } \\
\hline Employee & 45.7 & 14.5 & 50.5 & 42.8 & 23.2 & 37.1 \\
\hline Self-employed & 11.4 & 8.3 & 7.2 & 6.4 & 12.9 & 3.6 \\
\hline Retired & 25.4 & 7.8 & 15.1 & 34.6 & 25.0 & 29.9 \\
\hline Other Inactive & 12.5 & 18.6 & 17.7 & 12.9 & 55.8 & 23.7 \\
\hline Unemployed & 5.1 & 24.5 & 9.5 & 3.2 & 62.5 & 5.7 \\
\hline
\end{tabular}

Source: Author's calculations using EFF 2002 and BHPS 2000

(1) Asset-poor households are defined as those households with common net worth less than or equal to three times the monthly income poverty line. For a description of the common net worth measure see the appendix. The asset-poverty rankings of the countries and of the different population groups remain the same when the alternative poverty definitions are employed.

(2) We consider children every household member below 14 years of age.

(3) Educational levels are defined according to the International Standard Classification of Education designed by the UNESCO. For a more detailed description, see the appendix. 
Table 4

Logit regression on the probability of asset poverty in Spain and the United Kingdom (standard errors shown in parentheses)

\begin{tabular}{|c|c|c|c|c|c|c|c|c|}
\hline & \multicolumn{4}{|c|}{ Spain } & \multicolumn{4}{|c|}{ Spain vs. United Kingdom (1) } \\
\hline & \multicolumn{2}{|c|}{ Net worth } & \multicolumn{2}{|c|}{ Non-housing wealth } & \multicolumn{2}{|c|}{ Spain } & \multicolumn{2}{|c|}{ United Kingdom } \\
\hline & Coeff. & t-ratio & Coeff. & t-ratio & Coeff. & t-ratio & Coeff. & t-ratio \\
\hline Intercept & $\begin{array}{l}-3.7 \\
(0.35)\end{array}$ & -10.5 & $\begin{array}{l}-2.3 \\
(0.20)\end{array}$ & -11.4 & $\begin{array}{l}-2.9 \\
(0.28)\end{array}$ & -10.5 & $\begin{array}{l}-2.8 \\
(0.19)\end{array}$ & -14.2 \\
\hline \multicolumn{9}{|l|}{ Sex and Age of the hh. head } \\
\hline Female & $\begin{array}{l}0.01 \\
(0.15)\end{array}$ & 0.11 & $\begin{array}{l}0.01 \\
(0.09)\end{array}$ & 0.1 & $\begin{array}{l}-0.0 \\
(0.13)\end{array}$ & -0.05 & $\begin{array}{c}0.2 \\
(0.09)\end{array}$ & 2.6 \\
\hline$<25$ & $\begin{array}{c}1.7 \\
(0.39)\end{array}$ & 4.6 & $\begin{array}{l}0.78 \\
(0.39)\end{array}$ & 2.0 & $\begin{array}{c}1.8 \\
(0.36)\end{array}$ & 5.1 & $\begin{array}{c}2.5 \\
(0.22)\end{array}$ & 11.1 \\
\hline $25-34$ & $\begin{array}{c}0.9 \\
(0.22)\end{array}$ & 4.1 & $\begin{array}{c}0.4 \\
(0.16)\end{array}$ & 2.3 & $\begin{array}{c}0.8 \\
(0.19)\end{array}$ & 4.4 & $\begin{array}{l}1.42 \\
(0.15)\end{array}$ & 9.5 \\
\hline $35-44$ & $\begin{array}{c}0.3 \\
(0.21)\end{array}$ & 1.4 & $\begin{array}{c}0.3 \\
(0.13)\end{array}$ & 1.8 & $\begin{array}{c}0.3 \\
(0.18)\end{array}$ & 1.9 & $\begin{array}{c}0.6 \\
(0.15)\end{array}$ & 4.3 \\
\hline $55-64$ & $\begin{array}{l}-0.6 \\
(0.25)\end{array}$ & -2.6 & $\begin{array}{l}-0.3 \\
(0.14)\end{array}$ & -2.1 & $\begin{array}{l}-0.6 \\
(0.22)\end{array}$ & -2.9 & $\begin{array}{l}-0.1 \\
(0.18)\end{array}$ & -0.3 \\
\hline $65-75$ & $\begin{array}{c}-0.9 \\
(0.30)\end{array}$ & -3.2 & $\begin{array}{c}-0.4 \\
(0.18)\end{array}$ & -2.0 & $\begin{array}{c}-0.9 \\
(0.26)\end{array}$ & -3.5 & $\begin{array}{c}-0.4 \\
(0.23)\end{array}$ & -1.9 \\
\hline$>74$ & $\begin{array}{l}-1.3 \\
(0.30)\end{array}$ & -4.1 & $\begin{array}{l}-0.5 \\
(0.19)\end{array}$ & -2.3 & $\begin{array}{l}-1.2 \\
(0.27)\end{array}$ & -4.3 & $\begin{array}{l}-0.3 \\
(0.22)\end{array}$ & -1.4 \\
\hline \multicolumn{9}{|l|}{ Household type } \\
\hline One adult, without children (2) & $\begin{array}{c}0.9 \\
(0.18)\end{array}$ & 5.2 & $\begin{array}{c}0.2 \\
(0.12)\end{array}$ & 1.7 & $\begin{array}{c}1.1 \\
(0.16)\end{array}$ & 6.6 & $\begin{array}{c}0.9 \\
(0.10)\end{array}$ & 8.2 \\
\hline One adult, with children & $\begin{array}{c}0.4 \\
(0.55)\end{array}$ & 0.7 & $\begin{array}{c}0.5 \\
(0.41)\end{array}$ & 1.3 & $\begin{array}{c}0.2 \\
(0.53)\end{array}$ & 0.4 & $\begin{array}{c}1.1 \\
(0.22)\end{array}$ & 5.1 \\
\hline More than one adult, with children & $\begin{array}{c}0.2 \\
(0.17)\end{array}$ & 1.1 & $\begin{array}{c}0.3 \\
(0.11)\end{array}$ & 2.7 & $\begin{array}{c}0.04 \\
(0.15)\end{array}$ & 0.3 & $\begin{array}{c}0.2 \\
(0.13)\end{array}$ & 1.8 \\
\hline \multicolumn{9}{|l|}{$\begin{array}{l}\text { Education (3) and labour } \\
\text { status of hh. head }\end{array}$} \\
\hline Low & $\begin{array}{c}0.6 \\
(0.16)\end{array}$ & 3.4 & $\begin{array}{c}0.7 \\
(0.10)\end{array}$ & 7.2 & $\begin{array}{c}0.4 \\
(0.15)\end{array}$ & 2.6 & $\begin{array}{c}0.9 \\
(0.10)\end{array}$ & 8.5 \\
\hline High & $\begin{array}{c}-0.3 \\
(0.24)\end{array}$ & -1.3 & $\begin{array}{c}-0.6 \\
(0.14)\end{array}$ & -4.3 & $\begin{array}{c}-0.4 \\
(0.15)\end{array}$ & -2.1 & $\begin{array}{c}-0.5 \\
(0.15)\end{array}$ & -3.5 \\
\hline Employee & $\begin{array}{c}1.0 \\
(0.30)\end{array}$ & 3.3 & $\begin{array}{c}1.7 \\
(0.17)\end{array}$ & 9.7 & $\begin{array}{c}0.6 \\
(0.22)\end{array}$ & 2.6 & $\begin{array}{c}0.2 \\
(0.18)\end{array}$ & 1.0 \\
\hline Retired & $\begin{array}{c}1.1 \\
(0.37)\end{array}$ & 2.9 & $\begin{array}{c}1.6 \\
(0.21)\end{array}$ & 7.3 & $\begin{array}{c}0.8 \\
(0.30)\end{array}$ & 2.7 & $\begin{array}{c}0.7 \\
(0.25)\end{array}$ & 3.1 \\
\hline Other Inactive & $\begin{array}{c}1.7 \\
(0.35)\end{array}$ & 4.8 & $\begin{array}{c}2.2 \\
(0.21)\end{array}$ & 10.0 & $\begin{array}{c}1.2 \\
(0.29)\end{array}$ & 4.1 & $\begin{array}{c}1.5 \\
(0.20)\end{array}$ & 7.1 \\
\hline Unemployed & $\begin{array}{c}1.7 \\
(0.36) \\
\end{array}$ & 4.8 & $\begin{array}{c}2.41 \\
(0.25) \\
\end{array}$ & 9.4 & $\begin{array}{c}1.2 \\
(0.31) \\
\end{array}$ & 3.9 & $\begin{array}{c}1.6 \\
(0.28) \\
\end{array}$ & 5.6 \\
\hline Sample & & 5,143 & & 5,143 & & 5,143 & & 5,084 \\
\hline Pseudo R2 & & 0.09 & & 0.09 & & 0.08 & & 0.17 \\
\hline
\end{tabular}

Source: Author's calculations using EFF 2002 and BHPS 2000

(1) To compare Spain and the United Kingdom, the common net worth measure is employed. A detailed description of the wealth variables is provided in the appendix. Asset-poor households are defined as those households with wealth less than or equal to three times the monthly income poverty line. The results are not sensible to changes in the definition of poverty employed.

(2) We consider children every household member below 14 years of age.

(3) Educational levels are defined according to the International Standard Classification of Education designed by the UNESCO. For a more detailed description see the appendix. The reference household is a household with a male household head between ages 45 and 54 years who lives with other adults and without children, and where the head is self-employed, with a medium educational level. 


\section{Accounting for Poverty Differences between Spain and the United Kingdom}

All of our previous results suggest that the asset poverty-relevant characteristics are very similar in Spain and the United Kingdom. However, despite this similarity, the incidence of wealthpoverty among British households is more than twice that of Spain. This differential is mainly driven by the housing wealth component and may be caused by the different demographic structure in these two countries or by a genuinely larger vulnerability of British households to wealth poverty. In order to shed some more light on this issue, our purpose in this section is to quantify the contribution of each of these factors to building this difference.

As suggested by Biewen and Jenkins (2002), ${ }^{26}$ to understand differences in poverty rates across countries, it is necessary to separate the influence of the distribution of poverty-relevant characteristics from the influence of the conditional poverty functions. In our case, the comparison of the distribution of poverty-relevant characteristics reveals that the household distribution by sex, employment, and education of the household head do not differ significantly across countries. ${ }^{27}$ However, as shown in Table 5, important differences emerge regarding age and living arrangements. Thus, the proportion of households whose head is either under 30 years old or above 65 is significantly larger in the United Kingdom than in Spain, whereas the share of households between 30 and 65 years old is larger in Spain. Moreover, for all of the age groups considered, the proportion of single households in the United Kingdom is larger than in Spain. These differences may clearly contribute to explain the asset-poverty gap obtained using housing wealth. Thus, given that young and single households have more difficulties for saving and, especially, becoming homeowners, both due to the credit constraints they face and also to the absence of consumption economies scale, the fact that we find more of these households in the United Kingdom results in a significantly higher incidence of asset-poverty in this country.

The differences in the household structure have been already documented in the literature. In particular, the sociological literature (see Reher, 1998) points out the existence of two main family models: one with strong family ties, observed in Spain and other Mediterranean countries; and a second with weak family ties, observed mainly in Northern Europe and in the United States. A key distinction between these two models is that in a country with strong family ties, the share of young people living with their parents and the proportion of elderly co-residing with an adult sibling is larger than in countries with weak family ties. Motivated by the large variation in the emancipation age observed across countries, several recent studies have analyzed the determinants of leaving the parental home (Giuliano 2007, Becker et al. 2004). For Spain, Díaz and Guillo (2005) stress the role of the mother's housework as a public good to explain the propensity of young adults to co-reside with their parents. Martínez-Granado and Ruiz Castillo (2002) show that the probability of emancipation of Spanish youths crucially depends on the probability of finding a job, but it is also affected by housing costs and the labour status of other household members. Thus, some features of the Spanish labour market, such as the high unemployment rate and the frequency of temporary and low-pay jobs held by youth, would contribute importantly to delay the decision to leave the parental home. ${ }^{28}$

\footnotetext{
${ }^{26}$ These authors decompose differences in income poverty rates in Germany, the United States, and the United Kingdom using a shift-share counterfactual approach.

${ }^{27} \mathrm{~A}$ detailed comparison of the distribution of households by different characteristics in these two countries is presented in the appendix.

28 Indeed, both the unemployment and enrollment rates in higher education are among the highest in the EU (Toharia et al. 1998).
} 
Distribution of households by age and family type in Spain and the United Kingdom (percentage of households)

\begin{tabular}{|c|c|c|c|c|}
\hline \multirow[b]{3}{*}{ Age of the household hea } & \multicolumn{2}{|c|}{ Spain } & \multicolumn{2}{|c|}{ United Kingdom } \\
\hline & $\%$ & N & $\%$ & N \\
\hline & & & & \\
\hline$<30$ & 5.7 & & 11 & \\
\hline Single & 1.1 & 54 & 4.6 & 241 \\
\hline Non- single, without child & 2.9 & 149 & 2.9 & 153 \\
\hline Non- single, with child & 1.7 & 89 & 3.4 & 179 \\
\hline $30-44$ & 30.6 & & 27.6 & \\
\hline Single & 2.8 & 145 & 5.7 & 297 \\
\hline Non- single, without child & 8.4 & 433 & 5.9 & 307 \\
\hline Non- single, with child & 19.4 & 995 & 16 & 836 \\
\hline $45-54$ & 19.8 & & 16.1 & \\
\hline Single & 1.6 & 81 & 3.9 & 205 \\
\hline Non- single, without child & 13.1 & 675 & 8.3 & 432 \\
\hline Non single, child & 5.1 & 260 & 3.9 & 202 \\
\hline $55-64$ & 16.4 & & 13.3 & \\
\hline Single & 1.5 & 75 & 3.8 & 201 \\
\hline Non- single, without child & 14.1 & 726 & 9.2 & 480 \\
\hline Non- single, with child & 0.8 & 41 & 0.3 & 15 \\
\hline$>64$ & 27.6 & & 32.1 & \\
\hline Single & 8.3 & 427 & 18.3 & 956 \\
\hline Non- single, without child & 18.4 & 946 & 13.6 & 710 \\
\hline Non- single, with child & 0.9 & 45 & 0.2 & 8 \\
\hline Total & 100 & 5,143 & 100 & 5,222 \\
\hline
\end{tabular}

Source: Author's calculations using EFF 2002 and BHPS 2000

Given the results obtained in the previous section, the larger share of young and single households observed in the United Kingdom makes, other things being equal, the household structure of this country more vulnerable to asset-poverty than the Spanish one. Therefore, what is the contribution of the household structure to the difference in asset-poverty rates? To answer this question, we use counterfactual analysis. In particular, we estimate the counterfactual wealth distribution for Spain non-parametrically, assuming the characteristics of the British household structure. Following Bover (2008), ${ }^{29}$ we estimate the Spanish empirical wealth distribution as follows

$$
F_{S P}(r)=\operatorname{Pr}_{S P}(w \leq r)=\sum_{j=1}^{J} \operatorname{Pr}_{S P}(w \leq r \mid z=j) \times \operatorname{Pr}_{S P}(z=j),
$$

where $F_{S P}(r)$ indicates the probability of finding a Spanish household with wealth non-greater than $r, w$ indicates the household's wealth, and $j(j=1, \ldots, J)$ denotes the different household types considered. The empirical distribution is defined as a weighted sum of the conditional probabilities for each group j (the first term), where the weights are the population marginal probabilities of the

${ }^{29}$ This author analyses the contribution of household demographics to explain differences in the wealth distribution between Spain and the United States. 
different groups. According to this notation, the Spanish counterfactual wealth distribution can be easily derived as

$$
F_{S P}^{U K}(r)=\operatorname{Pr}_{S P}^{U K}(w \leq r)=\sum_{j=1}^{J} \operatorname{Pr}_{S P}(w \leq r \mid z=j) \times \operatorname{Pr}_{U K}(z=j),
$$

where the only difference with [1] is that the marginal probabilities of the different household types in Spain have been replaced by the British ones. Finally, using this distribution, we can compute the counterfactual poverty rate in Spain, relying on the British household structure in the following way

$$
P_{S P}^{U K}\left(t_{S P}\right)=\operatorname{Pr}_{S P}^{U K}\left(w \leq t_{S P}\right)=\sum_{j=1}^{J} \operatorname{Pr}_{S P}\left(w \leq t_{S P} \mid z=j\right) \times \operatorname{Pr}_{U K}(z=j)
$$

where $t_{S P}$ represents the Spanish asset-poverty line. To measure the impact of the household structure on the poverty rate, we can decompose the difference in asset-poverty rates between Spain and the United Kingdom as follows

$$
P_{S P}\left(t_{S P}\right)-P_{U K}\left(t_{U K}\right)=\left[P_{S P}\left(t_{S P}\right)-P_{S P}^{U K}\left(t_{S P}\right)\right]+\left[\mathrm{P}_{\mathrm{SP}}^{\mathrm{UK}}\left(t_{\mathrm{SP}}\right)-P_{U K}\left(t_{U K}\right)\right],
$$

where the terms in the first square brackets represent the share of the poverty gap explained by cross-national differences in household characteristics, while the terms in the second square brackets indicate the contribution due to differences in the conditional poverty function. Table 6 shows the results of the decomposition analysis. The first set of results corresponds to the classification of households used in Table 5, which differentiates 15 types of households according to the age of the head and the type of living arrangement. Furthermore, in order to check the robustness of the results, we replicate the analysis using an alternative classification that defines 12 groups using these same variables.

As shown in Table 6, the incidence of asset-poverty in Spain always increases when its actual household structure is replaced by the British household structure. The Spanish counterfactual poverty rate is larger than the real one in any of the specifications considered. In fact, the assetpoverty rate in Spain increases by more than one third when the British structure is assumed whatever asset-poverty threshold is used. Thus, the results show that differences in the age distribution and in living arrangements account for more than one quarter of the wealth-poverty gap between Spain and the United Kingdom, which is quite significant, given that we are comparing two industrialized countries with similar economic structures. However, the results of the decompositions suggest that a significant part of the asset-poverty gap between Spain and the United Kingdom is accounted for differences in the conditional poverty functions in these two countries. An important contribution to this difference is attributable to some groups of households, such as elder, female-headed, single, and lone-parent, for which, as it was pointed out when we described the asset-poverty profiles, the incidence of wealth-poverty in the United Kingdom is significantly larger than in Spain. However, in order to fully understand the contribution of these groups of households, it is necessary to analyze the extent to which the characteristics and the formation process of these households is comparable in the two countries, which is out of the scope of this paper. Moreover, many other factors would contribute to explain this differential. For instance, the income volatility caused by the high frequency of temporary jobs in the Spanish labour market clearly provides more incentives for the accumulation of a buffer stock of resources; the preferences for the intergenerational transfers of resources may 
not be the same in the two family models, which would affect importantly the wealth accumulation process in these two countries. Differences in attitudes toward risk, as well as in the capacity families have for saving, measured by the relationship between income earnings and consumption prices, are also important elements that must be taken into account for explaining differences in the incidence of asset-poverty. In any case, the analysis of all of these factors is left for future research.

Table 6

Decomposition of the poverty rate difference between Spain and the United Kingdom ${ }^{(1)}$

(all variables in percentage)

\begin{tabular}{|c|c|c|c|c|c|c|}
\hline & \multicolumn{3}{|c|}{ Spain } & \multicolumn{3}{|c|}{ Decomposition } \\
\hline & $P_{\mathrm{SP}}$ & $P_{\mathrm{SP}}^{\mathrm{UK}}$ & $\Delta(\%)$ & $\left(P_{\mathrm{SP}}-P_{\mathrm{SP}}^{\mathrm{UK}}\right)$ & $\left(P_{\mathrm{SP}}^{\mathrm{UK}}-P_{\mathrm{UK}}\right)$ & Total \\
\hline \multicolumn{7}{|l|}{ Classification (2) : 15 groups } \\
\hline$\%$ with zero or negative wealth & 12.2 & 16.4 & 33.8 & 55.3 & 44.7 & 100 \\
\hline $\begin{array}{l}\% \text { with wealth } \leq 3 \times \text { monthly } \\
\text { income poverty line }\end{array}$ & 13.1 & 17.7 & 34.9 & 31.7 & 68.3 & 100 \\
\hline$\%$ with wealth $\leq$ quarterly income & 13.5 & 17.9 & 33.2 & 27.9 & 72.1 & 100 \\
\hline \multicolumn{7}{|l|}{ Classification (3) : 12 groups } \\
\hline$\%$ with zero or negative wealth & 12.2 & 16.5 & 35.2 & 57.6 & 42.4 & 100 \\
\hline $\begin{array}{l}\% \text { with wealth } \leq 3 \times \text { monthly } \\
\text { income poverty line }\end{array}$ & 13.1 & 17.6 & 34.2 & 31.2 & 68.8 & 100 \\
\hline$\%$ with wealth $\leq$ quarterly income & 13.5 & 17.9 & 32.5 & 27.3 & 72.7 & 100 \\
\hline \multicolumn{7}{|c|}{ Source: Author's calculations using EFF 2002 and BHPS 2000} \\
\hline \multicolumn{7}{|c|}{ (1) Poverty rates are computed using the common net worth measure. } \\
\hline \multicolumn{7}{|c|}{$\begin{array}{l}\text { (2) The groups are defined according to the age of the household head and the type of living arrangement. We consider five age groups: under 30, } \\
30-44,45-54,55-64 \text {, and over } 65 \text {. The household types considered are single, non-single with children, and non-single without children. }\end{array}$} \\
\hline \multicolumn{7}{|c|}{$\begin{array}{l}\text { (3) In this case we consider four age groups: under 25, 25-44, 45-64, and over 65. The household types considered are single, non-single with } \\
\text { children, and non-single without children. }\end{array}$} \\
\hline
\end{tabular}

\section{Conclusions}

One of the main reasons individuals save is to build up a reserve of resources against future contingencies. Thus, wealth is central to the economic security of households, as it is the principal instrument households have to insure themselves against risk. Indeed, wealth is the main source of liquidity households have to overcome periods of economic hardship, since assets can be converted to cash or can be used as collateral in order to cover immediate consumption needs.

The main aim of this paper is to quantify and identify asset-poor households in Spain; that is, households that lack enough wealth to maintain a minimum welfare level during a period of time. Moreover, we perform this analysis using alternative definitions of asset-poverty that differ in the minimum level of welfare required to be maintained by running down household assets. For this work, we have used data in the first wave of the Spanish Survey of Household Finances conducted by the Bank of Spain in 2002. Our results reveal that households headed by a young person are the most vulnerable group. Indeed, the chance of being asset-poor reduces as the 
age of the head increases, especially for those that are over 55 years old. However, this result partially changes when the housing wealth component is excluded. In this case, the incidence of poverty presents a U-shape pattern, which indicates the problems households at the end of the life-cycle have in accumulating other types of wealth holdings. Additionally, households with low expected lifetime income are more vulnerable to asset-poverty. Indeed, households with a loweducated or inactive non-retired head face a higher risk of being wealth-poor than others. Interestingly, living arrangements also appear as an important factor that affects the possibility of wealth-poverty. Thus, single households with only one adult have a greater chance of being poor, especially those with dependent children. Various factors could explain the larger vulnerability of these groups. Thus, in addition to the income problems that usually urge this type of families, these households may also have more difficulties for saving because of the absence of consumption economies of scale and the larger liquidity constraints they face.

We use information from the British Household Panel Survey 2000 to compare the results obtained for Spain with those of the United Kingdom. As we show in the paper, these countries differ importantly in their wealth portfolio composition as well as in their family structure, which makes the comparison of these countries especially interesting. The results suggest that the characteristics of asset-poor households in the United Kingdom are very similar to those observed in Spain. However, regarding the extent of poverty, we find that the incidence of poverty in the United Kingdom is around twice that of Spain, where this difference is mainly driven by the housing wealth component. We use counterfactual distribution analysis to determine the extent to which the difference in asset-poverty rates is explained by a larger vulnerability of British households or by the distribution of poverty-relevant characteristics. Our results indicate that differences in the household structure account for more than 25 percent of the wealth-poverty gap, which suggests that the household formation process is a factor that must be taken into account when performing cross-national comparisons on asset-poverty. However, there is a significant share of the asset-poverty gap between these two countries which is accounted for differences in the conditional poverty functions. In particular, elder, female-headed, single, and monoparental households contribute significantly to this difference, as the incidence of asset-poverty among these groups in the United Kingdom is significantly larger than in Spain. This raises the question to what extent these households are comparable across countries, since their characteristics and their formation processes may differ significantly in these two countries. However, the contribution that this and other factors, such as the differences in attitude toward risk, social protection, or income volatility, make in explaining the asset-poverty gap is left for further research. 


\section{Appendix}

\subsection{Wealth definitions}

Table A.1

Wealth measures used in the analysis

\begin{tabular}{|c|c|c|c|}
\hline & Real assets & Financial assets & Debts \\
\hline Net worth $=$ & $\begin{array}{c}\text { Principal residence + } \\
\text { Other real estate + } \\
\text { Business equities + } \\
\text { Collectibles (1)+ }\end{array}$ & $\begin{array}{l}\text { Transaction accounts + } \\
\text { Deposits and saving accounts + } \\
\text { Total bonds + Stocks+ } \\
\text { Mutual and investment funds+ } \\
\text { Private pension schemes + } \\
\text { Life insurance+ Other financial } \\
\text { assets+ }\end{array}$ & $\begin{array}{l}\text { Mortgage debt (2) - } \\
\text { Non-mortgage debt (3) }\end{array}$ \\
\hline $\begin{array}{l}\text { Common net } \\
\text { worth }^{(4)}=\end{array}$ & $\begin{array}{c}\text { Principal residence + } \\
\text { Other real estate + }\end{array}$ & $\begin{array}{l}\text { Deposit and saving accounts + } \\
\text { Total bonds }+ \text { Stocks }+ \\
\text { Mutual and investment funds+ } \\
\text { Private pension schemes + } \\
\text { Life insurance + Other financial } \\
\text { assets }{ }^{(5)+}\end{array}$ & $\begin{array}{c}\text { Mortgage debt - } \\
\text { Non-mortgage debt - }\end{array}$ \\
\hline $\begin{array}{l}\text { Housing } \\
\text { wealth = }\end{array}$ & $\begin{array}{c}\text { Principal residence + } \\
\text { Other real estate + }\end{array}$ & & Mortgage debt - \\
\hline $\begin{array}{l}\text { Non housing } \\
\text { wealth = }\end{array}$ & \multicolumn{3}{|c|}{ Net worth (Common net worth) - Housing wealth } \\
\hline
\end{tabular}

(1) Notice that the value of other real assets like vehicles and other consumer durables is not included in the definition of net worth. As one of the referees rightly points out, these assets are unlikely to be used as cash in hard times as they are acquired to provide direct consumption services and their resale values are usually smaller than their consumption values. The category of collectibles includes the value of jewellery, works of art, and antiques.

(2) It includes every outstanding loan on the properties owned by the household.

(3) This is the sum of all financial commitments held by the household with non-mortgage guarantee.

(4) This measure includes all the assets and debts included in the net worth measure but business equities, transaction accounts, private pension schemes, and life insurance programs, whose value is not reported in the BHPS.

(5) In the BHPS, data on these assets is collected in two broad categories denominated savings and investments, where the first category includes the value of saving accounts and deposits, while the second reflects the value of fixed income securities, investment funds, shares, and other financial assets. 


\subsection{Accounting for differences in the probability of reporting a full questionnaire in the BHPS}

As we mention in the main text, not all the households initially interviewed in the tenth wave of the BHPS report all the information required about wealth holdings. If the probability of fullresponse varies across households, our sample will suffer a problem of representativeness. Therefore, to control for this potential bias we need to construct appropriate weights that preserve the population representativeness of our final sample. In particular, we follow the methodology used by Cantó et al. (2003) to control for the selection and the attrition problems they face in their analysis of poverty dynamics. Thus, let us define $S_{i}$ to be a random variable that equals 1 if a households is selected in the original sample (of size $S$ ) and, $R_{i}$ an indicator function that takes value 1 if the household belongs to the sub-sample (of size $R$ ) of households that report a full questionnaire. Then, the probability of full-response is given by:

$$
P_{i}\left(R_{i}=1\right)=P_{i}\left(R_{i}=1 \mid S_{i}=1\right) \times P_{i}\left(S_{i}=1\right), \quad i=1, \ldots \ldots, S,
$$

where the probability of being selected in the original sample, $P\left(S_{i}=1\right)$, is known because the cross-sectional weights provided in the BHPS are proportional to the inverse of this probability. Then, to determine $P_{i}\left(R_{i}=1\right)$ we only need to compute the probability of providing a fullquestionnaire conditioned to having been selected in the original sample, $P_{i}\left(R_{i}=1 \mid S_{i}=1\right)$. We estimate this probability using a logit regression on a set of households characteristics, whose results are available upon request. Then, the weight attached to a household $i$ that reports all the information is defined to be proportional to the inverse of the estimated probability of belonging to this group, re-scaled using a scaling factor $k$ to sum up the sub-sample size $(R)$ :

$$
w_{i}=\frac{k}{\hat{P}_{i}\left(R_{i}=1\right)}, \quad \text { s.t } \quad \sum_{\mathrm{i}=1}^{\mathrm{R}} w_{i}=\mathrm{R}
$$

\subsection{Education Coding}

To group households according the educational level of the head we follow the International Standard Classification of Education (ISCED) provided by the UNESCO:

- LOW includes no education, pre-primary, primary, lower secondary, compulsory and initial vocational education.

- MEDIUM includes upper secondary general education, basic vocational education, and post-secondary education.

- HIGH includes specialized vocational education, university/college education and (post)doctorate and equivalent degrees. 


\subsection{Household Structure in Spain and the United Kingdom}

The distribution of poverty-relevant characteristics is a factor that contributes to explain differences in the incidence of poverty across countries (Biewen and Jenkins, 2002). Thus, a poverty gap may be explained simply because of a larger presence of more vulnerable groups. Table A.3 shows the distribution by socioeconomic characteristics of British and Spanish households. In the case of Spain, given the bias that the over-representation of wealthy households in the EFF could introduce, we also describe the household structure using the information from the 2004 Survey of Living Conditions (Encuesta de Condiciones de Vida, ECV) and the 2001 European Community Household Panel (ECHP).

As the Table A.2 shows the distribution of households regarding the educational level and labour status of the household head is very similar in the two countries. This result is also

Table A.2

Socio-economic characteristics of Spanish and British households (all variables in percentage)

\begin{tabular}{|c|c|c|c|c|}
\hline & \multicolumn{3}{|c|}{ Spain } & \multirow{2}{*}{$\begin{array}{c}\text { United Kingdom } \\
\text { BHPS } 2000 \\
\end{array}$} \\
\hline & EFF 2002 & ECV 2004 & ECHP 2001 & \\
\hline \multicolumn{5}{|l|}{ Sex of hh. head } \\
\hline Male & 66.1 & 67.0 & 74.5 & 55.5 \\
\hline Female & 33.9 & 33.0 & 25.5 & 44.5 \\
\hline \multicolumn{5}{|l|}{ Age of hh. head } \\
\hline Age $<35$ & 14.3 & 12.3 & 18.5 & 20.0 \\
\hline Age $35-44$ & 22.0 & 20.6 & 25.22 & 18.6 \\
\hline Age $45-54$ & 19.8 & 19.4 & 20.57 & 16.1 \\
\hline Age $55-64$ & 16.4 & 17.1 & 13.91 & 13.3 \\
\hline Age $65-74$ & 17.4 & 15.7 & 11.69 & 14.9 \\
\hline Age $>74$ & 10.2 & 14.9 & 10.11 & 17.1 \\
\hline \multicolumn{5}{|c|}{ Civil status of $h h$. head } \\
\hline Never married & 11.1 & 13.7 & 23.1 & 16.2 \\
\hline Married & 71.2 & 66.0 & 62.4 & 52.6 \\
\hline Divorced & 5.1 & 5.6 & 3.8 & 14.2 \\
\hline Widow & 12.6 & 14.8 & 10.7 & 17.0 \\
\hline \multicolumn{5}{|c|}{ Education of hh. head } \\
\hline Low educated & 59.2 & 63.2 & 60.6 & 55.1 \\
\hline Medium educated & 25.7 & 15.9 & 15.4 & 33.7 \\
\hline High educated & 15.1 & 20.9 & 23.9 & 11.2 \\
\hline \multicolumn{5}{|c|}{ Labour status of hh. head } \\
\hline Employed & 45.7 & 42.0 & 53.0 & 42.8 \\
\hline Self-employed & 11.4 & 9.4 & 16.6 & 6.4 \\
\hline Retired & 25.4 & 26.2 & 15.5 & 34.6 \\
\hline Other Inactive & 12.5 & 16.5 & 9.1 & 12.9 \\
\hline Unemployed & 5.1 & 6.0 & 5.9 & 3.2 \\
\hline \multicolumn{5}{|l|}{ Household size } \\
\hline One & 15.2 & 15.6 & 17.1 & 36.4 \\
\hline Two & 25.7 & 27.2 & 25.2 & 32.0 \\
\hline Three & 24.3 & 23.8 & 14.5 & 14.2 \\
\hline Four & 24.3 & 24.7 & 21.6 & 11.7 \\
\hline Five or more & 10.6 & 8.9 & 21.7 & 5.7 \\
\hline \multicolumn{5}{|l|}{ Number of children } \\
\hline None & 72.2 & 74.8 & 72.7 & 76.2 \\
\hline One & 16.9 & 15.5 & 15.3 & 10.7 \\
\hline Two & 9.6 & 8.8 & 9.8 & 9.5 \\
\hline Three or more & 1.3 & 1.0 & 2.2 & 3.6 \\
\hline \multicolumn{5}{|c|}{ Principal residence ownership } \\
\hline No & 18.1 & 18.0 & 15.3 & 30.9 \\
\hline Yes & 81.9 & 82.0 & 84.7 & 69.1 \\
\hline
\end{tabular}

Source: Author's calculation using EFF 2002, ECV 2004, ECHP 2001, and BHPS 2000 
obtained when we look at the presence of children: in both countries more than 70 percent of households lack of children. As noted already in the text, the main differences between the two populations are observed regarding the age distribution and the type of living arrangement. In particular, young and old households have a large presence in the British population. Also, the number of single households in the United Kingdom is more than twice that of Spain (36 versus 15 percent), whereas the presence of households with three or more members in Spain is twice that in the United Kingdom (60 percent versus 31 percent). Moreover, the larger presence of single households among British households is related to the civil status of the head. Indeed, the proportion of households whose head is divorced or has never married is larger among British households which clearly contributes to explain the larger presence of single households observed in this country.

\section{References}

Alonso, J. (2009). "Social Security and Retirement across the OECD countries". Job Market Paper.

Ayala, L., and Palacio, J. I. (2000). "Hogares de baja renta en España: Caracterización y determinantes". Revista de Economía Aplicada, Vol. 8, No. 23, pp. 35-70.

Azpitarte, F. (2008). "The Household Wealth Distribution in Spain: The Role of Housing and Financial Wealth". ECINEQ Working Papers No. 83.

Banks, J., Blundell, R., and Smith, J. P. (2003). "Understanding Differences in Household Financial Wealth between the United States and Great Britain". The Journal of Human Resources, Vol. 38, No. 2, Special Issue on Cross-National Comparative Research Using Panel Surveys, pp. 241-279.

Bárcena, E., and Cowell, F., A. (2006). "Static and Dynamic Poverty in Spain, 1993-2000," Hacienda Pública Española, IEF, Vol. 127, No.4, pp. 51-77.

Barret, B. and McPeak, J. G. (2006). "Poverty traps and safety nets" in Poverty, Inequality and Development: Essays in Honour of Erick Thorbecke A. de Janvry and R. Kanbur (eds.) Springer (2006).

Becker, S. O., Bentolila, S., Fernandes, A., and Ichino, A. (2004). "Job Insecurity and Children's Emancipation". Institute for the Study of Labour (IZA) Discussion Papers 1046.

Biewen, M., and Jenkins, S. P. (2002). "Accounting for Poverty Differences between the United States, Great Britain and Germany". ISER Working Papers, No. 2002-14.

Bourguignon, F. and Chakravarty, S.R., (2003). "The Measurement of Multidimensional Poverty". Journal of Economic Inequality, Vol. 1, No 1, pp. 25-49.

Bover, O. (2004). "Spanish Survey of Household Finances (EFF): Description and Methods of the 2002 wave". Occasional paper No.0409, Bank of Spain.

Bover, O. (2008). "Wealth Inequality and household structure: U.S. vs. Spain". CEPR Discussion Paper No. 6680, February 2008.

Bover, O, Martínez-Carrascal, C., and Velilla, P. (2005). "The Wealth of Spanish Households: a Microcomparison with the United States, Italy and the United Kingdom". Economic Bulletin of the Bank of Spain 07/2005. 
Browning, M., and Lusardi, A. (1996). "Household Saving: Micro Theories and Micro Facts". Journal of Economic Literature, Vol. 34, No. 4, pp. 1797-1855.

Caner, A., and Wolff, E. N. (2004). "Asset Poverty in the United States, 1984-1999: Evidence from the Panel Study of Income Dynamics". Review of Income and Wealth, Series 50, Vol. 4, pp. 493-518.

Cantó, O., Del Río, C., and Gradín, C. (2003). "La evolución de la pobreza estática y dinámica en España en el periodo 1985-1995". Hacienda Pública Española/Revista de Economía Pública, Vol. 167, No. 4, pp. 87-119.

Cantó, O., Del Río, C., and Gradín, C. (2006). "Poverty Statics and Dynamics: Does the accounting period matter?". International Journal of Social Welfare, Vol. 15, No. 3, pp. 209-218.

Cantó, O., Del Río, C., and Gradín, C. (2007). "What helps households with children in leaving poverty? Evidence from Spain". Research on Economic Inequality, Vol. 14 , pp. 1-29.

Christensen, A.-K., Dupont J., and Schreyer P. (2005). "International Comparability of the Consumer Price Index: Owner-Occupied Housing". Paper prepared for the OECD Seminar, Inflation Measures: Too High---Too Low---Internationally Comparable? Paris, June 21-22.

Costa, Dora L., (2000). "From Mill Town to Board Room: the Rise of Women's Paid Labour". Journal of Economic Perspectives, Vol. 14, No. 4, pp. 101-122.

Díaz, A. and Guilló, M. D. (2005). "Family Ties and Labour Supply". Investigaciones Económicas, Vol. 29, No. 2, pp. 289-329.

Duclos, J.-Y. and Mercader-Prats, M. (1999). "Household Needs and Poverty: With Application to Spain and the U.K". Review of Income and Wealth, Vol. 45, No.1, pp. 77-98.

Gourinchas, P. O. and Parker, J. A. (2002). "Consumption Over the Life Cycle", Econometrica, Vol. 70, No. 1, pp. 47-89.

Giuliano, P. (2007). "Living Arrangements in Western Europe: Does Cultural Origin Matter?". Journal of the European Economic Association, Vol. 5, No. 5, pp. 927-952.

Hubbard, R. G. (1985). "Personal Taxation, Pension Wealth, and Portfolio Composition" The Review of Economics and Statistics, Vol. 67, No.1, pp. 53-60.

Hubbard, R. G., Skinner, J., and Zeldes, P. (1995). "Precautionary Saving and Social Insurance". The Journal of Political Economy, Vol. 103, No. 2, pp. 360-399.

Jappelli, T. (1990). "Who is Credit Constrained in the U.S. Economy? Quarterly Journal of Economics, Vol. 105, No. 1, pp. 219-34.

Kennickell, A. (1998). Multiple Imputation in the Survey of Consumer Finances.

Kennickell, A. (2000). Wealth Measurement in the Survey of Consumer Finances: Methodology and Directions for Future Research.

Martínez-Granado, M. and Ruiz-Castillo, J. (2002). "The Decisions of Spanish youth: A crosssection study". Journal of Population Economics, Vol. 15, No. 2, pp. 305-330.

Mumford, K. and Parera, A. (2001). "The Labor Force Participation of Married Mothers in Spain and Britain". Discussion Papers in Economics, University of York, No.2001/10.

OECD. 2006. Unemployment Outlook 2006. Boosting Jobs and Incomes. ISBN 92-64-02384-4

Reher, D. S. (1998). "Family ties in Western Europe: persistent contrasts". Population and Development Review, Vol. 24, No. 2, pp. 203--234.

Ruggles, P. and Williams, R. (1989). "Longitudinal Measures of Poverty: Accounting for Income and Assets over Time". Review of Income and Wealth, Vol. 35, No. 3, pp. 225--244. 
Short, K. and Ruggles, P. (2006). "Experimental Measures of Poverty and Net Worth: 1996". Journal of Income Distribution, Special issue on assets and poverty, pp. 8-21.

Sierminska, E., Brandolini, A., and Smeeding, T. (2006). "The Luxembourg Wealth Study: A Cross Country Comparable Database for Household Wealth Research", Journal of Economic Inequality, Vol. 4, pp. 375-383.

Tatsiramos, K. (2006). "Unemployment Insurance in Europe: Unemployment Duration and Subsequent Employment Stability". IZA Discussion Papers Series, No. 2280.

Taylor, M. F., Brice, J., Buck, N., and Prentice-Lane, E. (2007). British Household Panel Survey User Manual Volume A: Introduction, Technical Report and Appendices. Colchester: University of Essex.

Toharia L., Albert C., Cebrián I., García Serrano C., García Serrano I., Malo M.A., Moreno G., and Villagómez E., (1998). "El mercado de trabajo en España". McGraw-Hill/Interamericana de España, S.A.U.

Van den Bosch, K. (1998). "Poverty and Assets in Belgium". Review of Income and Wealth, Vol. 44, No. 2, pages 215-228.

Weisbrod, B. and Hansen W.L. (1968). "An Income-Net Worth Approach to Measuring Economic Welfare". American Economic Review, Vol. 58, pp. 1315--1329.

Wolff, E. N. (1990). "Wealth holdings and Poverty Status in the U.S.". Review of Income and Wealth, Vol. 30, No. 2, pp. 143-165.

Zagorsky, J. L.(2006). "Measuring Poverty Using both Income and Wealth". Journal of Income Distribution, Special issue on assets and poverty, pp. 22-40. 